\title{
Stonehenge Has Got a Younger Sister Ales Stones in Sweden Decoded
}

\author{
Nils-Axel Mörner ${ }^{1}$, Bob G. Lind ${ }^{2}$ \\ ${ }^{1}$ Paleogeophysics \& Geodynamics, Saltsjöbaden, Sweden \\ ${ }^{2}$ Archaeoastronomy, Malmö, Sweden \\ Email: morner@pog.nu
}

Received October 25, 2011; revised December 12, 2011; accepted December 23, 2011

\begin{abstract}
We report a novel finding that Stonehenge in England and Ales Stones in Sweden were built with the same basic geometry and using the megalithic yard as standard of measure. This opens quite new perspectives into cultural influence, travel and trading in the Bronze Age.
\end{abstract}

Keywords: Archaeoastronomy; Stone Calendars; Stonehenge; Ales Stones

\section{Introduction}

Stonehenge is a remarkable megalithic monument from the Neolithic period dating at about 3000 to 2000 BC. It is monumental and visited by about 1 million people every year. It must be held as one of the most important archaeological objects in the world. Numerous papers and books have been devoted to its construction and assumed practical/ceremonial use [1-6]. In 1963, Hawkins published an article in Nature entitled Stonehenge Decoded [7] where he quite convincingly demonstrated that Stonehenge was an archaeoastronomical calendar. This paper surely stands out as a benchmark paper. Stonehenge is, of course, on the World Heritage list.

Today, 38 years later, we trust we are able to claim Ales Stones Decoded. Ales Stones is a megalithic monument in southeast Sweden. It has the form of a $69.8 \mathrm{~m}$ long and $18.8 \mathrm{~m}$ wide ship composed of 57 erected blocks. The stone-ship is organized as a perfect calendar recording the annual motions of the Sun, the 12 months (eleven of 30 days and one of 35 days; i.e. in total 365 days per year) and the daily movements of the Sun with respect to zenith in the south-north line $[8,9]$. The monument has a remarkable location at the top of a $40 \mathrm{~m}$ high glacial moraine with a steep erosional cliff to the Baltic Sea (Figure 1). It is visited by some 0.7 million people every year.

\section{Built in the Bronze Age}

The stem and stern stones consist of quartzite. They are sharp-edged indicating quarrying. Their internal structure reveals its origin in the quartzite bedrock out-cropping some $30 \mathrm{~km}$ to the east $[8,10]$. The blocks are likely to have been transported from there to Ales Stones by rafts (or, maybe, pulled over the winter ice). From a landing place

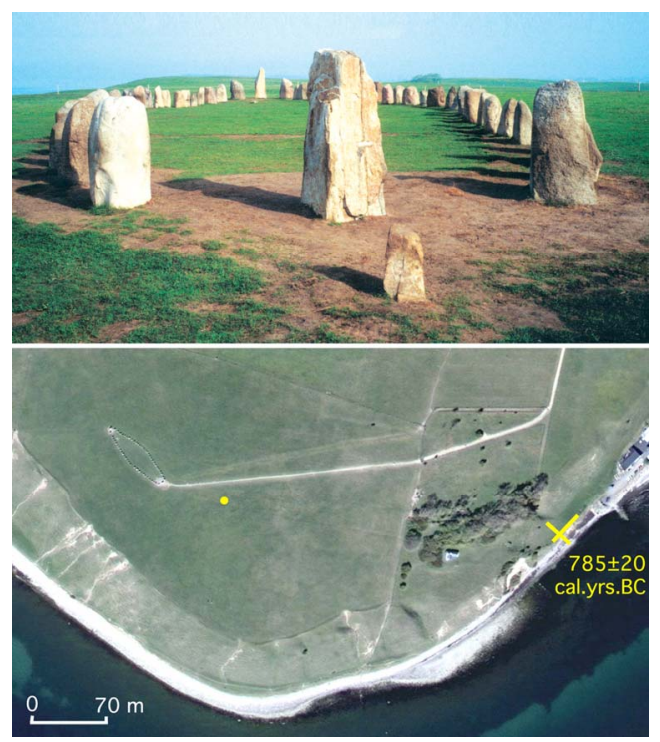

Figure 1. The stone-ship Ales Stones resting monumentally on the flat surface of a moraine ridge from the deglacial period some 13,000 years ago. The sea cliff is about $40 \mathrm{~m}$ high. Inserted picture shows the ship from the stern. Two stones marking the stem and the stern consist of quartzite quarried $30 \mathrm{~km}$ to the east. All the other stones seem to represent erratic boulders collected from the surface of the surrounding moraines. Yellow dot marks the site where an imprint depression of one of the stones was found and excavated in 2011 [12]. It is covered by eolian sand deposited at about $600 \mathrm{BC}$. The yellow lines at the shore mark sections where charcoal (dated $785 \pm 20$ cal. yrs BC) and mounds with bones from assumed offering were found, all covered by eolian sand from about $600 \mathrm{BC}$. 
at the foot of the cliff, the stones were then pulled up to the site of erection in the stem and stern of the ship. At the proposed landing place, there is a buried land surface with lots of bones (primarily of pigs, especially young pigs) and charcoal, radiocarbon dated at $785 \pm 20$ cal. yrs BC [8]. The surface is covered by eolian sand deposited at around $600 \mathrm{BC}$. Between this landing point and the stern stone, there are traces of a buried transportation way $[8,11]$. Here, too, the old land surface is covered by eolian sand deposited $600 \mathrm{BC}$.

All the other 55 stones in Ales Stones seem to be erratic boulders collected from the surface of the old glacial and late glacial deposits in the surroundings [10], not least the moraine ridge itself. Some of the stones show signs of severe wind erosion typical for the pre-glacial landscape. This summer, we excavated the imprint in the till surface of a huge block. The block was about $3.2 \times$ $1.2 \times 0.5 \mathrm{~m}$. One of the stones in Ales Stones (60 m away) seems to fit quite well into the imprint hollow. The old till surface and the imprint hollow are now covered by eolian sand deposited 600 BC. Consequently, the removal of the block, the transportation away and erection in Ales Stones must pre-date the wind blown sand at 600 BC [12]. There- fore, we conclude that Ales Stones were erected in the late Bronze Age (or earlier, but not later).

The individual stones in Ales Stones are full of cup marks, a favourite object in Scandinavian rock-carving from the Bronze Age (but also occurring in the Neolithic and Early Iron Age). Most important are the cup marks on the top of stone 8 from the stem stone and stone 8 from the stern stone (Figure 2) because they exhibit perfect solar alignments [8,9]. Therefore, they must have been cut into the tops of those two stones when the stones were erected and in place; i.e. in the late Bronze

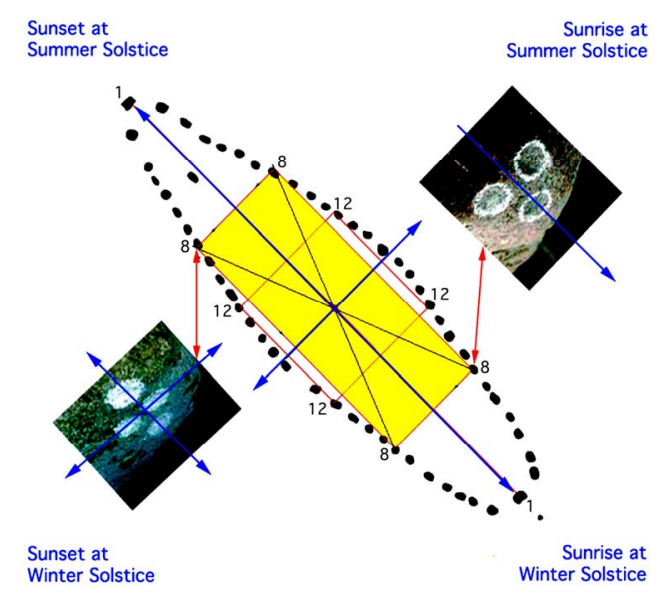

Figure 2. Ales Stones with the alignments (blue arrows) of the sunrise and sunset at Winter and Summer solstice. On the top of stones 8 in the NW and the SE, there are cup marks, which exhibit strict alignments to the solar motions [8]. The four number 8 stones form a rectangle marked in yellow.
Age at around 700- 800 BC (cf. below).

\section{Function and Basic Geometry}

Ales Stones is built so that, seen from the centre, the Sun rises over the stern stone at Winter solstice and sets over the stem stone at Summer solstice. The Sun rises at Summer solstice between the two stones marking the mid-ship in NE and sets at Winter solstice between the opposite stones in SW. Similarly, the Sun rise and Sun set at equinoxes occur over the $12^{\text {th }}$ stones marking the $\mathrm{E}-\mathrm{W}$ alignment. All the main six solar events are recorded in Figure 3. The alignments recorded can, of course, not be a mere coincidence. It must be the result of a careful planning. The cup marks on stones 8 in the west and the east (Figure 2) give the same alignments. This lends strong support for an interpretation in terms of an ancient calendar.

The stone arrangements also provides a record of the months, all of 30 days except for the $7^{\text {th }}$ month that had 35 days, making a total year of 365 days [8]. Sun rises over the stern stone on December 24 (Winter solstice) at 08.34 , over stone 3 on January 23 at 08.15 , over stone 9 on February 22 at 07.15 , over stone 12 on March 24 at 06.00, over stone 14 on April 23 at 04.40, over stone 15 on May 23 at 03.42 and over stone 16 on June 22 (Summer solstice) at 03.20. Sun sets over the stem stone on June 22 (Summer solstice) at 20.48, over stone 3 on July

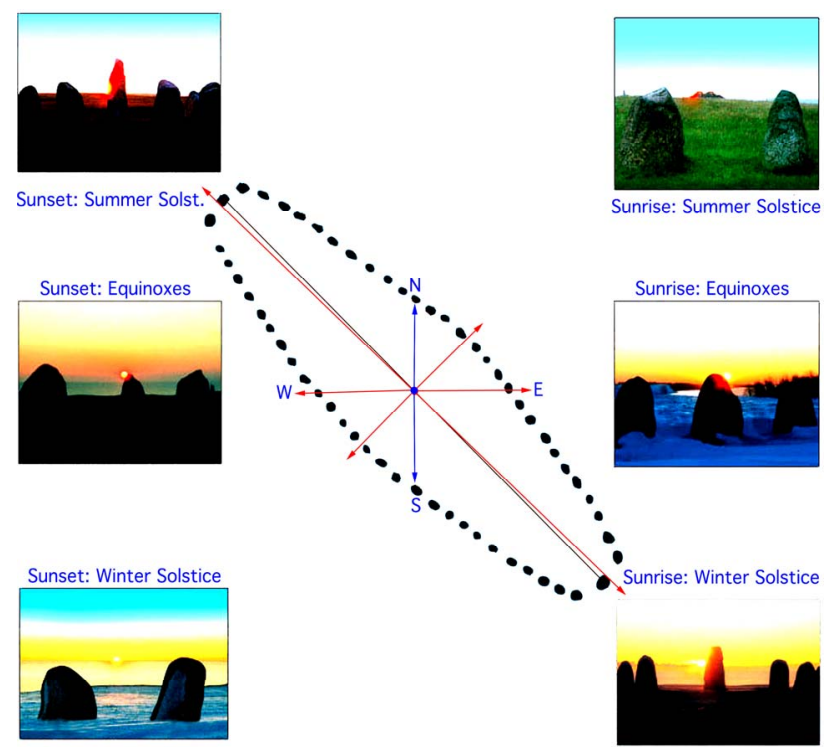

Figure 3. Ales Stones (with reconstructed shape at the stem; cf. Figure 2) and its very strict alignments with respect to the sunrise at Winter solstice, Spring equinox, Summer solstice and Autumn equinox, and the sunset at Winter solstice, Spring equinox, Summer solstice and Autumn equinox. There is a minor deviation of $38.5 \mathrm{~cm}$ or $0.77^{\circ}$ with respect to the strict NW-SE symmetry axis. This is consistent with an age of construction of around $700 \mathrm{BC}$ [8]. 
27 at 20.15, over stone 9 on August 26 at 19.15, over stone 12 on September 25 at 18.00, over stone 14 on October 25 at 16.40 , over stone 15 on November 24 at 15.42 and over stone 16 on December 24 (Winter solstice) at 15.30 . Every single step is recorded by photos taken from the centre of the ship [8]. This can hardly be understood in other terms than a carefully planned calendar.

The daily motion of the Sun is recorded by 16 stones, each one of which represents 1.5 hours. A pole in the centre inclined at $30^{\circ}$ to the north gives a shadow passing from stone to stone at an interval of 1.5 hours [8].

The alignments are very exact (Figure 3 ). There is a small deviation, however. The Sun rises at Winter solstice about $38.5 \mathrm{~cm}$ or $0.77^{\circ}$ east of the centre of the stern stone, and Sun sets at Summer solstice about $38.5 \mathrm{~cm}$ or $0.77^{\circ}$ west of the centre of the stem stone. This discrepancy is caused by the long-term changes of the tilt of Earth's rota- tional axis. Converted to time, this deviation implies an age of the construction of the calendar of about $700 \mathrm{BC}$ [8], an age that fits perfectly well with our stratigraphical records indicating that the stones were taken out of the ground and placed in the ship shortly before the sand drift at $600 \mathrm{BC}[8,11,12]$.

A recent finding is that the standard of measure in association with Ales Stones seem to fit with the Megalithic Yard (MY) [9]. This standard of measure was used all over the British Islands during the Neolithic and Bronze Age [13].

The form of a ship is, of course, the most basic shape of the Ales Stone monument. One may, however, also identify some other basic geometric signs. They are: 1) a rectangle of the 4 stones termed stones 8 (from the stem and the stern, respectively), two of which have special cup mark figures on their tops (Figure 2); 2) a circle through the corners of the before mentioned rectangle and the stones off the mid-ship alignments of the Sun rise at Summer solstice and Sun set at Winter solstice; and 3) the alignment of the Sun rise at Summer solstice (Figure 4). We use these 3 geometric signs in a comparison with the same basic geometry of the Stonehenge monument.

\section{Comparison with Stonehenge}

The original plan of Stonehenge given by Hawkins [7], includes 3 basic geometric factors: 1) the rectangle formed by the station stones; 2) the circle of the Aubrey Holes; and 3) the line of the first sunbeams at the Summer sol- stice (Figure 5). This is an important record of the basic geometry behind Stonehenge. The problem, however, is that the figure is not drawn to a fixed scale; rather it is a sketch expressing the basic principles [7].

In Figure 6, the monument is drawn in its correct proportions [3]. We have marked the basic three elements; 1 ) the rectangle of the station stones; 2) the circle of the Aubrey Holes; and 3) the sightline of the first Sun beams

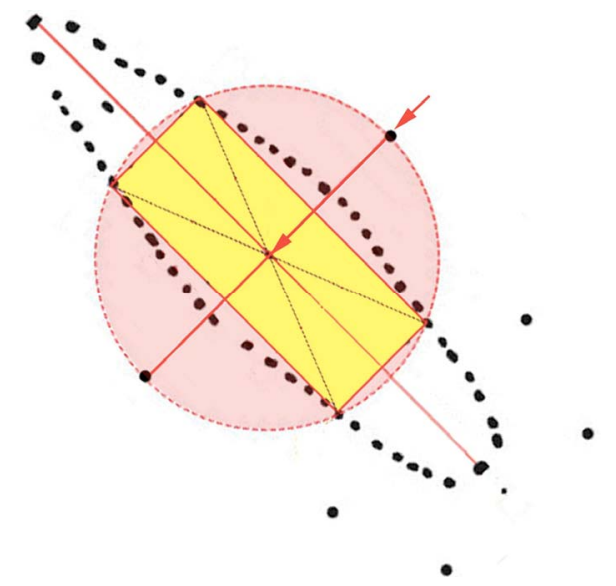

Figure 4. Besides the form of a ship, Ales Stones has a basic geometry consisting of a rectangle (yellow), a circle (pink) and the line of the first sunbeam at Summer solstice (red arrow). The length of the ship, the sides of the rectangle and the diameter of the circle suggests that the standard of measure was the Megalithic Yard [9,13].

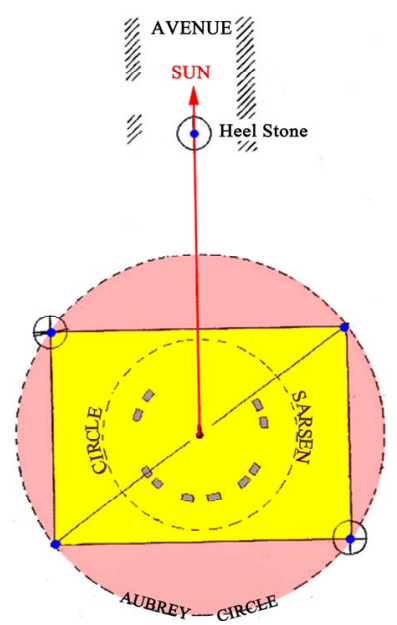

Figure 5. The original drawing of Stonehenge by Hawkins [7] can be simplified by 3 basic elements; the rectangle (of the Station stones), the Aubrey circle and the line of the first sunbeam at Summer solstice. The figure is a sketch, however, not drawn to a fixed scale.

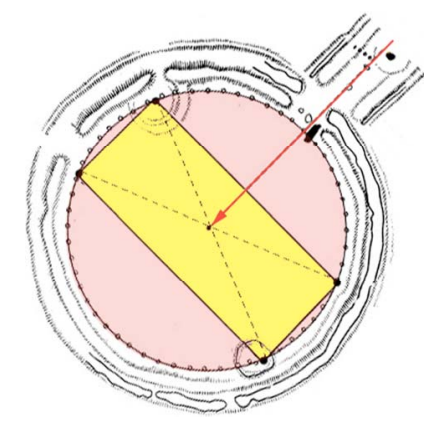

Figure 6. Stonehenge as drawn to a strict scale with its 3 basic elements marked; the rectangle (yellow), the circle (pink) and the alignment to the sunrise at Summer solstice (red arrow). 
at Summer solstice. This implies that both Stonehenge (Figure 6) and Ales Stones (Figure 4) seem to be built with the same basic geometry.

In Figure 7, we have made the 3 basic geometric parameters of Stonehenge (Figure 6) transparent, and superposed it on Figure $\mathbf{4}$ of Ales Stones. The agreement is striking: the two rectangles have almost the same proportions, the two circles overlap perfectly well, and the alignment of the first Sun beams at Summer solstice is identical. This can hardly be a coincidence. Rather does it seem to indicate that both monuments were built after the same basic geometric principle. This may sound astonishing because of geographic distance and difference in time. It can be taken as new facts pointing to quite another cultural interchange between Britain and Scandinavia than generally realized.

Other facts point in the same direction. "The boy with the amber necklace," buried at Boscombe Down, $5 \mathrm{~km}$ SE of Stonehenge, and dated at 1550 BC bear witness of travel and cultural interchange [14-16]. The isotopic composition of his milk teeth is indicative a childhood in the Mediterranean. The 90 amber beads in his necklace have a provenance from the south Baltic coasts. This provides evidence of long-distance migration and trading. The southeast part of Sweden may even have been some sort of trading centre [17-19].

The similarity in basic geometry of Stonehenge and Ales Stones and the application of the megalithic yard as a standard of measure at both sites provide quite strong arguments for a cultural connection, including migration and trading, between Britain and Southern Scandinavia in the Bronze Age.

\section{Conclusions}

In 1963, Hawkins presented his bench-mark paper entitled "Stonehenge decoded" [7]. We are now able the say the same about Ales Stones. Obviously, it was built as a sophisticated calendar. The stone ship of Ales Stones was erected in the late Bronze Age, judging from multiple converging age determinations $[8,11,12]$.

A novel finding, not previously presented, is that Stonehenge and Ales Stones are built with the same basic geometry. Furthermore, the standard of measure is the megalithic yard in both monuments.

Obviously, Britain and southern Scandinavia were linked by cultural influences, travel and trading in the Bronze Age.

Stonehenge belongs to the Neolithic period and Ales Stones to the late Bronze Age. The geometric linkage of the two monuments (Figure 7) reveals an influence from Britain to southern Sweden. One may say: "Stonehenge has got a younger sister - but so much more beautiful".

Finally, we find Ales Stones so remarkable both in beauty and in scientific value that it deserves to become

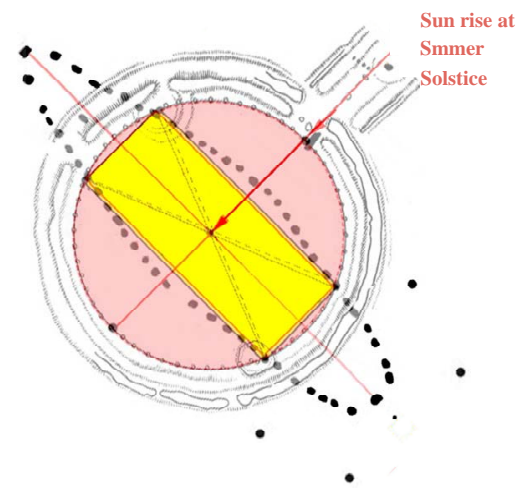

Figure 7. Superposition of Stonehenge (Figure 6; transparent) on top of Ales Stones (Figure 4). The 3 basic geometric elements the rectangle, the circle and the Summer solstice alignment are almost identical. This cannot be a mere coincidence. Rather does it seem to indicate that both monuments were built after the same basic concept. This would imply that there was quite another cultural exchange in the Bronze Age than generally assumed. It fits, however, with new findings in England [14-16] and Sweden [8,17-19].

incorporated on the World Heritage list.

\section{REFERENCES}

[1] G. S. Hawkins, "Stonehenge Decoded," Souvenir Press, Cambridge, 1966.

[2] Ch. Chippindale, “Stonehenge Complete," Thames \& Hudson and Ithaca, London, 1983.

[3] R. J. C. Atkinson, "Stonehenge and Neighbouring Monuments,” English Heritage, London, 1993.

[4] D. Souden, "Stonehenge, Mysteries of the Stones and Landscape,” English Heritage, London, 1997.

[5] R. Heath, “Stonehenge,” Wooden Books Ltd., London, 2001.

[6] C. Nutt, “The Stonehenge Story,” English Heritage, London, 2004.

[7] G. S. Hawkins, “Stonehenge Decoded,” Nature, Vol. 200, 1963, pp. 306-308. doi:10.1038/200306a0

[8] B. G. Lind and N.-A. Mörner, "Mykenska och Fenisiska spår på Österlen,” Stjärnljusets Förlag, Malmö, 2010.

[9] B. G. Lind and N.-A. Mörner, "Kopplingen StonehengeAles Stenar (Summary: Stonehenge-Ales Stenar: Built with the Same Basic Geometry and with the Megalithic Yard as Standard),” Stiärnljusets Förlag, Malmö, 2011.

[10] J. Bergström, E. Daniel, E. Herner, K.-E. Kornfält, M. Strömberg and H. Wikman, "Ales Stenar-Stenarnas Historia,” Ale, Historisk Tidskrift för Skåne, Vol. 4, 1988, pp. 1-13.

[11] P. Wikström, “Arkeologiska Undersökningar Med Markradar vid Ales Stenar,” Radarteam AB, Rapport 10-901, 2010, pp. 1-12.

[12] N.-A. Mörner, “Geological Investigations,” Report to the Swedish Board of Antiquity on the excavation at Ales Stenar in 2011, Part 2, pp. 1-24 (in Swedish). 
[13] A. Thom and A. Burl, "Stones and Standing Stones: Britain, Ireland and Brittany,” Oxford, 1990.

[14] J. A. Evens, C. A. Chenary and A. P. Fitzpatrick, "Bronze Age Childhood Migration of Individuals near Stonehenge, Revealed by Strontium and Oxygen Isotope Tooth Enamel Analysis," Archaeometry, Vol. 48, No. 2, 2006, pp. 309-321. doi:10.1111/j.1475-4754.2006.00258.x

[15] J. A. Evens, J. Montgomery, G. Wildman and N. Boulton, "Spatial Variations in Biosphere 87Sr/86Sr in Britain," Journal Geological Society, Vol. 167, No. 1, 2010, pp. 14. doi:10.1144/0016-76492009-090

[16] J. A. Evens, "Stonehenge Boy Was from the Mediterranean (2010), The boy with Amber Necklace: Bronze Age Teenager Buried at Stonehenge Had Travelled to Visit Site from the Mediterranean,” http://www.bgs.ac.uk/staff/profiles/0394.html

[17] N.-A. Mörner, B. G. Lind and G. Possnert, "Heimdall's Stones at Vitemölla in SE Sweden and the Chronology and Stratigraphy of the Surroundings," Geografiska Annaler, Vol. 91A, No. 3, 2009, pp. 205-213.

[18] N.-A. Mörner and B. G. Lind, "Mediterranean Bronze Age trading centre in SE,” In: S. P. Paraminopoulos, Ed., The Atlantis Hypothesis-Commentary 2008, Heliotopos Publ., Athens, 2010.

[19] N.-A. Mörner and B. G. Lind, "Long-Distance Travel and Trading in the Bronze Age," Atlantis 2011, 3rd International Conference, Santorini, 25-26 June 2011, 4 Pages. (Also: In: S. P. Paraminopoulos, Ed., The Atlantis Hypothesis-Commentary 2011, Heliotopos Publ., Athens, 2012, in Press). 